\title{
Estate Planning for the Non-Native Son
}

\author{
Brent M. Abel*
}

$M^{\text {ANY persons have come to California after acquiring substantial prop- }}$ erty elsewhere. If such property is attributable to earnings during marriage, special estate planning questions arise. It is the purpose of this article to consider these questions and put forward a few tentative answers.

Originally the Civil Code contamed no provisions dealing specifically with the commumity or separate character of property brought to California by married persons. The early cases uniformly held, in consonance with usual conflicts principles, that California land purchased with funds earned by the husband in another state was the separate property of the husband, if his earnings were his separate property when received. ${ }^{1}$ The rule held whether the spouses, when the issue arose, were residents of California ${ }^{2}$ or of another state. ${ }^{3}$ It produced harsh effects upon the death of either spouse, for the rights of dower and curtesy, of which the spouses had generally had the benefit in the state where the funds were acquired, did not attach to California land. ${ }^{4}$ Hence it was possible for the husband to cut off his wife completely by his will, at least where the entire estate consisted of realty.

The legislature moved to the wife's $\mathrm{s}^{5}$ rescue with an amendment ${ }^{6}$ to Section 164 of the Civil Code, providing that California real property, and personal property wherever situated, "acquired while domiciled elsewhere, which would not have been the separate property of either if acquired while domiciled in this state, is community property" (emphasis added). To a decision of the supreme court that the amendment was not intended to apply retroactively to property acquired before it became effective, ${ }^{7}$ the legislature responded with a further amendment ${ }^{8}$ expressly making the quoted provision retroactive. This directly raised the question of constitutionality of the retroactive feature (a point reserved in the Frees ${ }^{\theta}$ case), which was an-

* Member, San Francisco Bar.

1 Kraemer v. Kraemer, 52 Cal. 302 (1877); Estate of Niccolls, 164 Cal. 368, 129 Pac. 278 (1912). Of course land purchased with funds which would have been separate if acquired while the spouses were Cahifornia residents was likewise separate property. See Estate of Burrows, 136 Cal. 113, 68 Pac. 488 (1902).

2 Kraemer v. Kraemer, Estate of Burrows, both supra note 1.

3 Estate of Warner, 167 Cal. 686, 140 Pac. 583 (1914).

4 Car. Crv. Code $\$ 173$. See Leflar, Community Property and Conflict of Laves, 21 Calrf. L. REv. 221, 227 (1933).

5 For simphicity, and except as otherwise indicated, earnings will be deemed to be earnings of the husband in the discussion which follows.

${ }^{\circ}$ Cal. Stats. 1917, p. 827.

$\tau$ Estate of Frees, 187 Cal. 150, 201 Pac. 112 (1921).

8 Cal. Stats. 1923, p. 746.

9 Supra note 7. 
swered negatively in Estate of Drishaus. ${ }^{10}$ There the supreme court denied the power of the legislature to apply the ainendment to previously acquired property. So far unconsidered was the basic question of whether the legislature could, by the aniendment, constitutionally convert separate property acquired after the amendment into community property. In Estate of Thornton, ${ }^{11}$ the amendment foundered completely on a square holding that to apply it to accomplish conversion of the husband's separate property into community property merely by the act of bringing it into Califormia was both an abridgment of privileges and immunities and a taking of property without due process of law. ${ }^{12}$

The dissent in Thornton ${ }^{13}$ hinted at a way out. The constitutional power of the states to determine succession to property has never been doubted. Furthermore a change in the laws of succession does not deprive anyone of a vested property right, either on the giving or the receiving end. The power to will one's property may be limited or abolished completely, and an heir has only an expectancy which the constitution does not protect. Hence, while the legislature could not constitutionally provide that property acquired elsewhere should become community property upon bemg brought to California, it could still dictate that succession thereto (so the reasoning went) should be determined as if it were community property. This result it sought to achieve by Section 201.5 of the Probate Code: ${ }^{14}$

Upon the death of either husband or wife one-half of all personal property, wherever situated, heretofore or hereafter acquired after marriage by either husband or wife, or both, while domiciled elsewhere, which would not have been the separate property of either if acquired while domiciled in this State, shall belong to the surviving spouse; the other one-half is subject to the testamentary disposition of the decedent, and in the absence thereof goes to the surviving spouse, subject to the debts of the decedent and to administration and disposal under the provisions of Division III of this code.

The current estate planning problems of new California residents center about this section and the history, often recounted by the courts, which led to it.

\section{THE BASTC PROBLEM}

It is not the purpose of this article to suggest legislative changes or a new judicial approach ${ }^{15}$ to the questions dealt with in the cases discussed

\footnotetext{
10199 Cal. 369, 249 Pac. 515 (1926).

111 Cal. 2d 1, 33 P.2d 1 (1934).

12 Although the 1917 and 1923 amendments have thus been substantially eviscerated, they remain in the section, a trap for the unwary practitioner.

13 Supra note 11.

14 Cal. Stats, 1935, p. 2248, hereinafter referred to simply as "Section 201.5."

15 See, for example, Justice Traynor's concurring opinion in Boyd v. Oser, 23 Cal. 2d 613, 145 P. 2d 312 (1944); Armstrong, "Prospective" Application of Changes in Community Property Control-Rule of Property or Constitutional Necessity?, 33 CALIF. L. Rev. 476 (1945).
} 
above. Rather the objective is to consider practicable methods of dealing with the tools which the legislature and the courts have in their wisdom already provided. A few of the typical problems are raised by a simple set of facts:

Husband and wife, married in 1920, have lived all their lives in Illinois, where the husband has accumulated life savings of $\$ 300,000$ froin his earnings. Neither spouse owned any property at marriage and neither has since received any by gift, bequest, devise or inheritance. In 1952, they move to California where they purchase an apartment house for $\$ 100,000$, to which title is taken in the husband's name alone. They bring with them in addition $\$ 200,000$ in marketable securities. They have children and grandchildren. Both spouses wish to provide amply for the survivor, but their secondary objective is to conserve their property for their descendants.

What can be done to enable the spouses to accomplish their purpose?

\section{The Husband's Problems}

How much of the property is subject to disposition by the husband's will if his wife survives? Under Section 201.5, one-half of all the personal property belongs to the surviving wife. California has the power constitutionally to determine the rights of succession to personal property of its residents and, the statute being valid under this primciple, the wife is entitled to one-half of the securities when the husband dies. That half does not pass under the husband's will. ${ }^{16}$

What about the apartment house? Section 201.5 does not touch it, being limited to personalty. ${ }^{17}$ While the legislature undoubtedly has the power, constitutionally, to determine devolution of real property within the state, it has not in this instance exercised it, for Thornton ${ }^{18}$ had held that Section 164 of the Civil Code could not be considered as a statute of succession. Therefore the entire interest in the apartment house is subject to testamentary disposition by the husband. ${ }^{10}$

${ }^{10} \mathrm{~A}$ question may well arise as to whether the half going to the wife is nevertheless subject to administration in the husband's estate, as in the case of community property (Car. Prov. CODE $\S 202$ ). The tert of $\S 201.5$ appears to make only the half passing under the husband's will so subject. If, however, the balf passing to the wife outside the will is not subject to administration (and to payment of creditors' claims) the anomolous result is that creditors are worse off here than if the estate were community property. This is wholly inconsistent with the concept that until his death the entire estate is separate property of the husband.

17 The holding in In re Way's Estate, 157 P. 2d 46 (1945) that the section applied also to realty purchased with personal property which, had it been retained, would have been subject thereto was disapproved by implication in In re Miller, 31 Cal. 2d 191, 187 P. $2 \mathrm{~d} 722$ (1947) (an inheritance tax case) where it is said (31 Cal. 2d at 198): "Why the Legislature in the latter enactment (\$201.5) omitted the express reference to real property does not appear." The holding in Miller was that real property in that form was subject to inheritance tax as if it were the decedent's separate property, even though it had been purchased with funds representing earning accumulated in a common law state.

18 Supra note 11.

19 In many, and perhaps most instances of this kind, husband and wife (contrary to the assumption in the present case) would have taken title to the apartment house in joint tenancy. 
What of the federal estate tax? The husband's gross estate includes all property to the extent of his interest therein at the time of his death. ${ }^{20}$ Since the real property has remained his separate property and is subject to disposition by his will, it is a part of his gross estate. What of the one-half interest in the personal property which belongs to the wife under Section 201.5? The practical effect of that section, it may be argued for the husband's executor, is to reduce the husband's ownership of that half, by operation of law, to a life estate. But Section 164 of the Civil Code cannot effect any change in the nature of the husband's interest during his lifetime, ${ }^{21}$ and he has retained until his death the income from the property and the power to convey it absolutely without his wife's consent. His interest in the one-half of the personal property which belongs to the wife upon his death is therefore equivalent, the Bureau of Internal Revenue might say, to an interest in property transferred by him with a reservation of a life estate, or, alternatively, to a revocable transfer. In either case, it would be included in his gross estate. ${ }^{22}$

Is the property which under Section 201.5 belongs to the wife on her husband's death to be subtracted from the husband's gross estate in determining his adjusted gross estate for the purpose of limiting the marital deduction ${ }^{23}$ The answer is clearly negative here. No portion of the property, notwithstanding the provisions of Section 164 of the Civil Code, has at any time been held "as community property under the law of any state."24 Furthermore, one original goal of the marital deduction was to equalize the estate tax consequences, at least to some extent, of separate as compared to community ownership, ${ }^{25}$ and this purpose is thwarted if the gross estate includes any separate property which must be subtracted in determining the limits of the marital deduction.

As to the California inheritance tax, it has been pointed out elsewhere ${ }^{26}$

If so, they may be in default for failure to file federal and California gift tax returns, for not many people know without legal alvice that the purchase of property in joint tenancy with funds of one joint tenant is a gift by him to the other. U. S. Treas. Reg. 108, $\S 86.2$ (a) (5) (1944); Cal. Adngrov. Code, tit. 18, § 80(b).

20 INT. REv. CODE § 811(a).

21 See supra note 11.

22 INT. REv. CODE $§ 811$ (c) and 811 (d). No doubt an eager revenue agent would also contend that the one-half interest which passes to the wife on the husband's death is also included in his gross estate by $\$ 811(\mathrm{~b})$, which includes "any interest therein of the surviving spouse existing at the time of the decedent's death as dower, curtesy, or by virtue of a statute creating an estate in lieu of dower or curtesy." (emphasis added) While this section does not include community property, it may include the wife's interest in the present case, which, as already noted, is not a community property interest.

23 INT. REv. CODE § 812 (e)(2)(B).

24 Ibid.

25 SEN. REP. No. 1013, 80th Cong., 1st Sess. § II, « B2, to accompany II. R. REP. No. 4790, 80th Cong., 1st Sess. (later the Revenue Act of 1948).

203 Stan. L. Rev. 616 (1951). 
that the Inheritance Tax Law may produce a capricious difference between the tax on real, as distinguished from personal, property, since the law follows the distinction between real and personal property made by Section

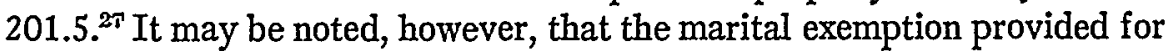
by the present law ${ }^{23}$ largely corrects (however inadvertently) the former result of discriminating against realty as compared to personalty. ${ }^{20}$

Summarizing the husband's situation, it is plain that he can dispose by his will of the entire real property and one-half of the personal property, but for federal tax purposes the entire real and personal property may be included in his gross estate, but they will not be subtracted in determining the limits of the marital deduction. Inheritance-tax wise, the transfer of the real property by the husband's will is fully subject to the Inheritance Tax Law (subject, however, to the marital exemption), while perhaps only one-half of the personalty is subject thereto. ${ }^{30}$

\section{The Wife's Problems}

In determining the amount of property subject to disposition by the wife's will, a major difficulty is immediately revealed in case the husband survives. Under Section 201.5, upon the wife's death, one-half of the personal property is expressly made subject to her testamentary disposition. But under the law of Illinois, whence the spouses came, the property all belonged to the husband. By attempting to give the wife power to dispose of one-half, the legislature has, it would appear, made another attempt to do what the supreme court in Thornton has said it cannot do, namely, to take away from the husband a major interest in the property simply because of the move to California. ${ }^{31}$ The saving principle which makes Section 201.5 effective in case the husband dies first (that California can control succession to property of a decedent in any manner it sees fit) is inapplicable for the reason that the wife has during the husband's lifetime no interest whose devolution the legislature can control. ${ }^{32}$ Therefore no part of the personal

27 CAL. REv. \& TAX CODE $\$ 13555$; In re Miller, supra note 17.

28 Cat. Rev. \& TAX CODE $\$ 13805$ (Cal. Stats. 1950, p. 361).

29 Since the real property has not been converted into community property (CAL. CTV. CODE $\$ 164$ being ineffective for this purpose, supra note 11), it remains the husband's separate property and therefore qualifies for the marital exemption. If the personal property were not deemed for inheritance tax purposes to be commumity property (CAL. REv. \& TAX CODE $\$ 13555$ ), the new marital exemption might overcompensate for the former inconsistency.

30 See note 22 , supra and text pertaining thereto.

31 The situation is analogous to Boyd v. Oser, supra note 15 , holding that the 1923 amendment to $\$ 164$ of the Civil Code (giving the wife testamentary power over one-half of the community property, where before she had no such power) could not be applied to property acquired or traceable under the source rule to property acquired before 1923 .

32 There are no appellate decisions on this point, but the conclusion seems inescapable. Unfortunately the findings of fact in Logan v. Forster, 114 A.C.A. 723, 250 P.2d 730 (1952) prevented direct consideration of the question in that case. 
property may be disposed of by the wife's will, notwithstanding the express language of Section 201.5.33

As to the real property, the result is the same, but for a different reason: the legislature has apparently not even purported to give her the right to dispose of the property by her will, ${ }^{34}$ except by the provisions of Section 164 of the Civil Code, already declared futile by the courts. ${ }^{35}$

Thus, if the wife dies first, no property is included in her gross estate for federal estate tax purposes ${ }^{36}$ for her death effects no change of interests in either the real or the personal property. Nor is there any transfer of property upon her death which is subject to California inheritance tax. Since she has no power to transfer the property by her will, it remains the husband's. ${ }^{3 T}$

If the wife leaves no will, of course the husband takes all, regardless of the result under the law of Illinois. ${ }^{38}$ The interest of heirs other than the husband was only an expectancy which the California legislature can and does defeat by Section 201.5. Only the portion of 201.5 which purports to give the wife testamentary power during the husband's life is invalid.9

${ }^{33}$ In the dissent in the Estate of Thornton, supra note 11, and in the opinion in In re Miller, supra note 17 , both the theory justifying $\$ 201.5$ and the effect of that section were described in terms which were, it is submitted, erroneous if read to mean that the wife bad testamentary power over any of the property if she died first. See In re Miller, supra note 17 at 196, 187 P.2d at 725 where it is said: "Unlike the earher legislation which had been declared unconstitutional, this statute [\$ 201.5] does not purport to rearrange property rights between living husbands and wives in marital property brought into this state upon their change of domicile to California. On the contrary, it is a succession statute apparently enacted in pursuance of the theory of the dissenting opinion in the Thornton case, that such legislation affecting the descent of of property would not contravene constitutional guarantees since the 'rights of testamentary disposition and succession are wholly subject to statutory control.' Estate of Thornton ..." (emphasis added) Testamentary disposition of one's own property is wholly subject to statutory control, but the legislature cannot give to $A$ testamentary power over the property of $B$, at least while $B$ is still hiving. Boyd v. Oser, supra note 15.

34 Unless the construction placed on $\$ 201.5$ in Estate of Way, supra note 17, is correct, which is highly unlikely, in view of In re Miller, supra note 17.

${ }^{35}$ Estate of Thornton, supra note 11.

36 A cautious executor, however, might well feel compelled to file a federal estate tax return setting forth all of the facts, for in the absence of a judicial decision holding that $\S 201.5$ is ineffective to give the wife any testamentary powers when the liusband survives, the safe course is obviously to avoid the penalties of failing to file a return (INT. REv. CODE $\S 894$ ) and to start the period at the expiration of which the executor may be discharged from personal liability for the tax (INT. REv. CoDE §825).

${ }^{37}$ For inheritance tax purposes, the personalty is deemed commumity (CAL. REV. \& TAX CODE $\$ 13555$ ) but, whether it is deemed to pass to the husband on her death or to be his already, there is no tax (id. $\S 13553$ ).

38 The question would probably only arise in the case of those who moved here from other commumity property jurisdictions where all the community property does not pass to the surviving spouse, absent a will (e.g., Texas, where one-half of the community property goes to issue, if any survive).

${ }^{39}$ As to whether property falling within $\S 201.5$ is deemed community or separate on the death of the surviving spouse for the purpose of applying $\$ \$ 228$ and 229. of the Probate Code, 


\section{LIFE INSURATYCE}

Section 201.5 also raises questions about life insurance. Normally the incidents of ownership of an unmatured policy and the proceeds of a matured policy have the same character, whether community or separate, as the premiums..$^{40}$ Assume that the husband in the example discussed above acquired a policy of ordinary life insurance on his own life in Illinois in 1930. The wife is the beneficiary but the husband, by the policy provisions, is its sole owner. Premiums continue to be paid after the spouses move to Califormia.

If the husband dies first, the policy proceeds are payable entirely to the wife. Since he is the owner of the policy (and also because he has paid the premiums), the proceeds are included in his gross estate. ${ }^{41}$ Even if a benefciary other than the wife is designated, it would follow from the principle of Thornton ${ }^{42}$ that the entire proceeds are payable to the named beneficiary. Payment of premiums out of earnings while in Illinois and out of Illinois savings while in California would preserve the separate character of the policy, ${ }^{43}$ notwithstanding Section 164 of the Civil Code, as amended. ${ }^{44}$

Suppose, however, that the wife dies first, leaving her entire estate to the children. Does her estate have any claim to the policy? Section 201.5, taken literally, purports to give her the right to dispose of a one-half interest therein by her will, for the policy is personal property and "would not have been the separate property of either [spouse] if acquired while domiciled" in California. Here the careful executor and the careful insurance conipany may be at loggerheads. The executor inust act to take the wife's assets into his hands, but recognition by the imsurer that the wife's estate

see Estate of Perkins, 21 Cal. 2d 561, 134 P. 2 d 231 (1943) and Estate of Ball, 92 Cal. App. 2d 93, 206 P.2d 1111 (1949). The decision in the former case, which classifies property as community or separate even when brought to California after the death of one of the spouses, appears highly questionable on the point of statutory construction of $\S 228$, although the constitutional power to cover the matter by legislation is beyond question.

$40 \mathrm{New}$ York Life Insurance Co. v. Bank of Italy, 60 Cal. App. 602, 214 Pac. 61 (1923), Estate of Castagnola, 68 Cal. App. 732, 230 Pac. 188 (1924), Traveier's Insurance Co. v. Fancher, 219 Cal. 351, 26 P. 2 d 482 (1933), Grimm.v. Grimm, 26 Cal. 2d 173, 157 P. 2 d 841 (1945), Estate of Wedemeyer, 109 Cal. App. 2d 67, 240 P.2d 8 (1952).

41 INT. REv. CODE $\S 811(\mathrm{~g})$. The hife insurance in this imstance is apparently not within the provisions of U. S. Treas. Reg. $105, \S 81.27$ (a) (1951) providing that only half the proceeds of a policy paid for with community premiums is included in the husband's gross estate.

42 Supra note 11.

43 See Field v. Bank of America, 100 Cal. App. 2d 311, 223 P.2d 514 (1950).

44 Supra note 6 . Payment of the policy proceeds to the named beneficiary would in any event, under $\$ 10172$ of the Insurance Code, discharge the company unless the wife made a claim prior to such payment.

45. To the extent that premiums have been paid while the spouses are residents of California, the pokicy has been "acquired" while the spouses are domiciled here. But, under the "source rule" (supra note 31 ) this fact is probably immaterial. 
has an interest is in derogation of the policy provision that the husband is the owner..$^{48}$

These are questions which can best be dealt with, of course, while both spouses are living. From the insured's side, agreement between husband and wife, by endorsement on the policy or otherwise, is desirable, having due regard to tax consequences. On the company's side, it should be the practice to review policies of persons known to have moved to California, in order that the problems may be pointed out to the policy holder and later controversy avoided. Informal inquiry among insurance companies doing busmess in California indicates that company practice is far from uniform, and in some instances totally lacking, in this regard.

\section{CONCLUSION}

From the foregoing discussion of the testamentary powers of the two spouses, at least two conclusions are apparent:

1. The illogical fact that, if the wife survives, all of the real property, but only half the personal property, is subject to the husband's testamentary disposition, while the whole of both real and personal property are, or at least may be, included in his gross estate for federal estate tax purposes.

2. The seemingly sound, but as yet judicially unconsidered, conclusion that, if the husband survives, none of the property is subject to disposition by the wife's will, or included in her gross estate for federal tax purposes, notwithstanding the provisions of Section 201.5.

It follows, if these conclusions are correct, that if the wife dies first there will be no federal estate tax on her death but a very substantial tax on the husband's subsequent death. If, however, the husband dies first, and his will takes advantage of the marital deduction, there will be a smaller tax on his death than would be due were he to survive his wife, but a further tax, in approximately an equal amount, will also be payable on the subsequent death of the wife.

A casual glance at the federal estate tax rates indicates that the total tax excision out of the property after both have died will be greater by many thousand dollars if the wife dies first than if the husband dies first. It is also true that the wife will have less to live on if she survives the husband than will the husband if he survives her. The former result is undesirable because it impedes the secondary objective of ultimately passing a maxinum of property to descendants, while the latter is unfortunate because in

46 In the case of a policy whose premiums are paid with funds clearly community in character (i.e., where the spouses luave always lived in a community property state), such a provision cannot bind the wife without her consent. Furthermore, in such cases, the Bureau of Internal Revenue asserts that on the wife's prior death one-lalf the value of the policy on the husband's life must be included in ler gross estate. U.S. Treas. Reg. 105, § 81.27(a) (1951). See also, Rev. Rul. 48, 1953 INT. Rev. BuIr. No. 7, p. 8 (dealing with community character of policies purchased with community funds by residents of Louisiana and Texas). 
normal course the needs of a widow are likely to be greater than those of a widower. From the point of view of descendants, the optimum estate plan taxwise achieves two equal net estates ${ }^{47}$ regardless of which spouse dies first. In the present case a plan aimed at this objective will not harm the wife, since the resources available to her as a widow may thereby be reduced to a lesser extent by taxes on the husband's estate..$^{48}$

What can be done to equalize the two taxable estates? An inter vivos agreement between the spouses that the entire property is to be held thenceforth as post-1927 community property would certainly achieve the result, but would no doubt entail gift tax consequences, ${ }^{40}$ the effect of any such agreement being to create equal present interests where the spouses each previously had something other than that. Annual transfers by the husband to the wife, designed to take advantage of the lifetime exemption, annual exclusion and marital deduction in the federal gift tax law, and of the annual exclusion and specific exemption in the California law, should be effective although their effectiveness will obviously be reduced if either spouse dies before the estates of the spouses are equalized or within three years thereafter. ${ }^{50}$

One possible form of inter vivos agreement might recite the doubt as to the efficacy of Section 201.5 to give the wife the right to dispose of any interest on her prior death and for an adequate and full consideration Inoving from wife to husband provide that the wife should, in the event of her prior death, have the powers purported to be conferred by Section 201.5. Wholly apart from the tax question, such an agreement would be a useful clarification of the rights of the spouses.

What adequate and full consideration can the wife offer? Suppose she agrees to give up her right to receive half the personal property outright if the husband dies first. The agreement would refer to the legal doubt as to whether she had the power to dispose on her prior death of one-half the personal property and provide that she would have that power in consideration of renouncing her right to take one-half if the husband dies first. In other words, by the agreement each spouse acquires the undisputed right to

47 As used here, the term "net estate" means the gross estate less deductions, but not less the specific exemptions, provided for in the federal estate tax law.

48 Even if the estates of busband and wife are equalized inter vivos, the husband may decrease the taxes on his prior death still further by talking advantage of the marital deduction, although this would in turn imcrease the wife's gross estate on her later death.

49 Int. Rev. Code $\$ 1000$ (see also Int. Rev. Code 1004(a) (3)). CaL. Rev. \& Tax Code $\S 15303$. If the property had joint tenancy character when brought to California, or was theretofore held in tenancy by the entirety, an agreement to convert to new-type community property would probably entail no gift tax. Furthermore there are many smaller estates in which there will be no tax (although it may be necessary to file returns) because of the exemptions and exclusions under both state and federal law.

50INT. REv. CoDE $\$ 811$ (a). 
dispose of one-half of the personal property by will if he or she dies first, the only difference being that the half as to which the husband acquires such right is the second half, while the wife's is the first. It may be that actuarially, by reason of the difference in sex or ages, the likelihood is that one spouse will live longer than the other. But the "adequate and full" requirement may well be met here, or may reduce the net gifts below the exemption, so that no gift tax liability would result. Furthermore, it would seem that the agreement would not constitute a transfer in contemplation of death by either spouse, regardless of how soon thereafter the death of either or both might occur. ${ }^{51}$

This type of agreement is obviously not a complete answer. To acquire the right to dispose of any of the personal property by will on her prior death, the wife has had to renounce the right to receive half on the husband's prior death. This may be too dear a price for the more wary of her sex. The real property may provide a sedative. Absent an agreement, the husband has the power to dispose of it $\mathrm{m}$ its entirety by will. A present transfer of a part interest therein, or an undertaking to devise such an interest to her by his will, may be a desirable or necessary part of the agreement.

The reader is left to his own devices in determining whether, in preparing such an agreement, he need make his peace with the United States Supreme Court and Merrill v. Fahs.52 There, in an antenuptial agreement, the wife gave up all marital rights in the husband's property in exchange for the creation of a trust for her benefit. This was not consideration in money or money's worth at all, said the court. The estate tax provision ${ }^{53}$ declaring that release of marital rights should not constitute "consideration in money or money's worth" should be read into the gift tax provisions ${ }^{54}$ taxing transfers for less than adequate and full consideration. Without elaborating, it seems clear that the present problem is not at all in pari materia with the subject matter and purpose of Merrill $v$. Fahs. To be sure, the wife gives up the right to take half the property under Section 201.5 if the husband dies first. Even assuming that this is a "relinquishment ... of a statutory estate created in lieu of dower or curtesy, or of other nuarital

51 Of course, on these facts alone, the contemplation of death question cannot arise on the death of the first spouse to die anyway. If the husband dies first, the entire property will be included in his gross estate, he having by law (in addition to the right to receive the income for hife from the whole) the power to dispose of one-half and by agreement of the wife the power to dispose of the other half. If the wife dies first, she has by the agreement the right to dispose of one-half. In either case has the decedent made a transfer of property which may be included in his or her estate.

52324 U.S. 308 (1945).

53 INT. REv. Code $\S 812$ (b).

G4 INT. REv. CODE $\S 1002$. 
rights ..., ,"155 it is a perfectly bona fide attempt by the spouses to avoid future controversy as to the effect of substantive enactments which the state legislature has forced upon them. Furthermore, the wife acquires in exchange testamentary powers which, if the analysis contained above is correct, she did not have before. Putting it another way, there is a mutual transfer or exchange of testamentary powers (the wife giving the husband the power to dispose by his will of one-half the property and he giving a similar power to her) rather than a release of any rights of the wife within the meaning of the statute. If it be said that this is a distinction without a difference, there are other distinctions of substance which in most cases will be applicable.

Any such agreement as to the character of the property, and any such annual transfers, may, and, if the tax considerations are important to the spouses, should, be accompanied or followed later by wills creating such interests as will exclude from the taxable estate of the surviving spouse any interest which has already been taxed in the estate of the first to die. ${ }^{56}$

It would be absurd to imply that the foregoing represents any more than a cursory treatment of the myriad substantive and tax problems created by Section 201.5. No attempt has been made to deal with the bugaboo of commingling which would loom large if the spouses moved to California in the middle of the husband's earning years rather than later. The problems resulting from a failure of the spouses to agree while both are living are untouched. The use of the doctrine of election of the surviving spouse to take under the will of the first to die as a possible means of dealing with Section 201.5 has not been treated. But the purpose of this article will have been attained if the need for forehanded planning in this field has been sufficiently emphasized, and if the point has been made that, whether tax considerations are relevant to a particular case or not, lifetime attention to the problems of Section 201.5 is essential.

55 IvT. Rev. CoDe $\$ 812$ (b). Apparently under Merrill v. Fahs, supra note 52 at 313, we must read the entire sentence whence this quotation comes into INT. REv. CoDE $\$ 1002$.

66 For example, by the use of a simple trust (elaborated, if desired, by emergency and spendthrift provisions) with income payable to the surviving spouse and remainder to descendants per stirpes, either equally or as appointed by the surviving spouse pursuant to special power of appointment. 